\title{
5. \\ GOVOR KNJIŽEVNOG LIKA I GOVOR DOKUMENTA: JEDNA EPIZODA IZ PROLJEĆA IVANA GALEBA
}

\section{Bojan Đorđević}

UDK: 821.163.42Desnica V.:002.1

Izvorni znanstveni članak

Sažetak: U radu se donose dosad nepoznati podaci o advokatskom i pravobranilačkom delovanju Vladana Desnice u Splitu tridesetih godina prošlog stoleća, a koji su pohranjeni u u Fondu Ministarstva pravde Kraljevine Jugoslavije u Arhivu Jugoslavije u Beogradu. Tih dokumenata nema mnogo. Uglavnom su službenog karaktera i svedoče o Desničinoj revnosti i ispravnosti kao državnog činovnika. Međutim, jedan predmet, u vezi sa procesom protiv više lica iz Splita i Dubrovnika, vođen pred Sudom za zaštitu države, kao posledicu imao je Desničin izveštaj o nepravilnostima u istražnom postupku, koji je on podneo u svojstvu službenika Državnog pravobranilašstva. Zanimljivost ovog dokumenta leži u činjenici da je on u neposrednoj vezi sa Desničinim romanom Proljeća Ivana Galeba.

Ključne rečì: Vladan Desnica, Split, komunistički pokret, dokument, književni lik, prototekst

7 ridesete godine dvadesetog stoleća bile su za Vladana Desnicu godine građenja činovničke karijere. Pošto je 1930. godine svršio studije prava u Zagrebu, počeo je da radi u advokatskoj kancelariji svog oca Uroša u Splitu. Treba odmah naglasiti da je ova advokatska kancelarija bila jedna od uglednijih, i to ne samo u Dalmaciji, da je iz godine u godinu bivalo sve više predmeta i slučajeva, posebno otkada je Uroš Desnica kancelariju iz Obrovca preselio u Split, te da se upravo na prelazu iz treće u četvrtu deceniju prošloga stoleća ukazala potreba za više službenika. Jer, politički aktivan (član Narodne radikalne stranke i poslanik u Narodnoj skupštini), Uroš Desnica je od 1929. godine bio još više involviran u politički život. Godine 1932. postao je senator. Zanimljivo, u enciklopedijskim 
prilozima uglavnom se ne pominje da je bio i član Vrhovnog zakonodavnog saveta Kraljevine Jugoslavije. Kako je, dakle, njegova kancelarija imala puno posla, to je on još 1929. godine primio jednog pripravnika. Isto je učinio i sledeće godine sa svojim sinom Vladanom. U izveštajima ove advokatske kancelarije koji su stizali u Ministarstvo pravde Kraljevine Jugoslavije nema, naravno, pomena Vladana Desnice, iako se može pretpostaviti da je te izveštaje on redigovao i davao im konačni oblik (jer su to uglavnom i radili pripravnici). U dokumentima koji se čuvaju u Arhivu Jugoslavije, u fondu Ministarstva pravde Kraljevine Jugoslavije, zasad smo pronašli samo dva pomena Vladana Desnice za vreme njegova službovanja u advokatskom uredu svog oca. Krajem aprila 1931. godine dr Uroš Desnica obavestio je načelnika za advokatske poslove u Ministarstvu pravde Kraljevine Jugoslavije da će obaviti dvonedeljno službeno putovanje u Beograd, gde ide na zasedanje Vrhovnog zakonodavnog saveta, čiji je član. Na kraju je dodao: „Tekuće poslove obavljaće u mom odsustvu advokatski pripravnik Vladan Desnica."1 Takođe, godine 1933. Uroš Desnica je podneo neku predstavku Apelacionom sudu u Splitu. Zasedanje po ovoj žalbi održano je 23. i 24. maja 1933. godine, a pred Apelacionim sudom nastupio je „pripravnik Vladan Desnica“.”

\section{II}

Godine 1934. Vladan Desnica je stupio na dužnost u Državnom pravobranilaštvu u Splitu. ${ }^{3} \mathrm{U}$ tom svojstvu napredovao je do ranga višeg pristava, položivši sudski ispit 1936. godine. ${ }^{4}$ Ni dokumenti o tom razdoblju Desničine činovničke karijere nisu brojni u Fondu Ministarstva pravde, jer je on, po subordinativnom principu, svoje izveštaje uglavnom slao u Zagreb. Retko kada je imao potrebu da se obraća direktno Ministarstvu pravde. To je bilo obavezno kada bi tražio odsustvo, što je on činio 1934. godine, kao i 1936. i 1937. godine. Sva tri puta naveo je da jednomesečno odsustvo traži „iz ličnih razloga“.5 Nema nikakve sumnje da su u pitanju bili porodični događaji - godine 1934. ženidba sa Ksenijom Carić, a 1936. i 1937. godine rođenje dveju kćeri, najpre Olge pa Jelene. Jedan zanimljiv dokument u ovom fondu, međutim, svedoči da je Desnica kao službenik Državnog pravobranilaštva imao i povremenih neprijatnosti. Krajem februara 1938. godine monsinjor Petar Dominis iz Šibenika je uputio žalbu Ministarstvu pravde Kraljevine Jugoslavije. Radilo se o nekom sukobu oko imanja, koje je po Dominisovom uverenju pripadalo Katoličkoj crkvi, a „uzurpirali su ga nesavjesni pojedinci“. Dominis se, naravno, obratio sudu, koji je, međutim, presudio u korist tih „nesavesnih pojedinaca“. Naposletku se krajem februara

\footnotetext{
Arhiv Jugoslavije (dalje: AJ), Fond Ministarstva pravde Kraljevine Jugoslavije (63)-29/1931-607.

AJ 63-48/1933-175; 202; 323.

3 U Opštem upitniku Ministarstva finansija Narodne Republike Hrvatske, 1946. godine, sam Desnica je upisao: „Do 1934 advokatski koncipijent u Splitu, od 1934 činovnik Državnog Pravobranioštva u Splitu." Videti: Drago RoksanDIĆ, „Ratni dani Vladana Desnice“, Intelektualci i rat 1939. - 1947. Zbornik radova s medunarodnog skupa Desničini susreti 2012. (ur. Drago Roksandić i Ivana Cvijović Javorina), sv. 2, Zagreb 2013., 548.

4 Videti biografiju Vladana Desnice koju je sačinio Dušan Marinković u: Vladan Desnica, Hotimično iskustvo: diskurzivna proza Vladana Desnice. Knjiga druga (prir. Dušan Marinković), Zagreb 2006., 226.

Videti: AJ 63-148/1934-71; AJ 63-337/1936-25; AJ 63-252/1937-48.
}

5 
1938. godine obratio Ministarstvu pravde, a ono je naložilo Državnom pravobranilaštvu u Splitu da slučaj ispita. Zadatak da proveri činjenice i izrekne mišljenje o tome da li je u postupanju suda prekršen zakon bio je poveren Vladanu Desnici. Očigledno da je Desničino mišljenje potvrđivalo sudsku presudu pa se Dominis žalio i na njega. Desnica je, po službenoj dužnosti, morao da razgovara sa monsinjorom, ali je ovaj to shvatio kao uvredu i požalio se lično Ministarstvu pravde na „drskost ovdašnjeg pravobranioca koji se usudio isleđivati me poput kakvoga mjesnog sudije“. 6

Ipak, i među ovim oskudnim dokumentima našao se jedan izveštaj Vladana Desnice od izuzetnog značaja ne samo za njegov službenički lik i karakter, i ne samo za istoriju komunističkog pokreta u Dalmaciji, već i za jedan važan momenat iz Desničine biografije, a iznad svega za njegov rad na romanu Proljeća Ivana Galeba.

\section{III}

Priča počinje novembra 1935. godine, ${ }^{7}$ kada su u Zagrebu uhapšeni Đorđe Mitrović i Franjo Kralj, kod kojih je nađen materijal tzv. Zembilja (Zemaljskog biroa Komunističke partije Jugoslavije). Iz tog materijala videlo se da oni održavaju veze sa Pokrajinskim komitetom KP Jugoslavije za Dalmaciju u Splitu. Provala je omogućena zahvaljujući hapšenju splitske javke - Anke Galić. ${ }^{8} \mathrm{Na}$ osnovu informacija dobijenih od nje, a potom i sledećih dvoje uhapšenih - Ivana Majnarića i Anke Berus - uhapšeno je ukupno deset članova Pokrajinskog komiteta iz Splita i Dubrovnika. Svi oni formalno su uhapšeni zbog rasturanja raznih levičarskih brošura te lista Proleter. Tokom istrage, a i docnije, pred sudom, svi oni su poricali da su članovi tada zabranjene Komunističke partije. Jedna od optuženih, Anka Berus, izjavila je, recimo, da je „mislila da se radi samo o feminističkom pokretu i antifašističkom frontu“.? Relja Vlak, pak, uporno je poricao da je bio član komunističke organizacije, ali je priznao da je svome zetu Ivanu Mariću „učinio nekoliko usluga “. ${ }^{10}$ Posle šestomesečne istrage, optuženi su izvedeni pred Državni sud za zaštitu države. Petoro njih je oslobođeno, među njima i Ivan Marić. Osuđeni su, 25. juna 1936. godine, trgovac Relja Vlak, prodavačica Tonka Marić, profesorka Anka Berus, zemljoradnik Vicko Jelaska i činovnik Ivan Majnarić. Svi oni su osuđeni, kako se u presudi veli, kao „članovi udruženja koje ima za svrhu propagandu komunizma“. ${ }^{11} \mathrm{U}$ posebnom procesu osuđen je stolar Ivan Benevoli (rođeni Splićanin), koji je bio veza u Dubrovniku. U obrazloženju presude je istaknuto:

Ustanovljeno je vođenim izviđajima, da je Split bio sedište pokrajinskog komiteta komunističke partije Jugoslavije za Dalmaciju, koji je komitet održavao direktne veze sa centralnim

\footnotetext{
6 AJ 63-33/1938-114.

Dokumenta o ovome videti u: AJ, Fond Državnog suda za zaštitu države (135)-10/1936; 135-14/1936.

Ljubiša Ristović - Savo KržAvac, Robija, kovačnica komunista, sv. 2, Zagreb 1968., 24.

AJ 135-10/1936.

Isto.

AJ 135-14/1936.
} 
komitetom u Beču, a istovremeno i indirektne preko „Zembilja“ u Zagrebu. Pokrajinski komitet je imao na svojoj teritoriji potreban broj adresa i javki, putem kojih je slat propagandistički komunistički ilegalni materijal. ${ }^{12}$

$\mathrm{Na}$ suđenju optuženima, prvooptuženi Ivan Majnarić tvrdio je da je „pred policijskom vlasti bio grubo primoran da i sebe i druge tereti “. ${ }^{13}$ Dakle, žalio se na zlostavljanje i torturu. Majnarića je branio dr Ivan Ribar. On je poslao pismenu predstavku Ministarstvu pravde Kraljevine Jugoslavije, žaleći se na „nečuvenu torturu“ nad njegovim branjenikom „dok bijaše ispitivan u Splitu“. ${ }^{14}$ Zanimljivo je da na postupke zagrebačke policije, koja je kasnije preuzela ispitivanje, nije imao nikakvih primedbi. ${ }^{15}$ Radilo se, zapravo, o Majnarićevom priznanju, očigledno iznuđenom, da ga je Ivan Marić učlanio u partiju „neizvesnog dana 1933. godine“ te da je za Marića prenosio knjige i brošure još od leta 1934. godine, a ne tek od avgusta 1935, kako je najpre Majnarić tvrdio. ${ }^{16} \mathrm{~S}$ obzirom da se žalba odnosila na postupak prema Majnariću dok je bio isleđivan u Splitu, Ministarstvo pravde je naložilo Državnom pravobranilaštvu u Splitu da ispita slučaj. Izveštaj je podneo Vladan Desnica, koji tek što je položio ispit za višeg pristava. Desničin izveštaj je vrlo kratak i u suštini se svodi na to da optuženome u samom sudskom postupku „nisu povređena građanska prava niti je prema njemu nezakonito postupano, što i sam optuženik tvrdi i. ${ }^{17}$ Desnica je u ovom slučaju, praktično, ustanovio da Državno pravobranilaštvo nije ovlašćeno da ispituje žalbe na policijsko postupanje pa je jednostavno svom kratkom izveštaju priložio lekarski nalaz, a u samom izveštaju samo napomenuo da su Majnariću, „prema liječničkom izvještaju bila polomljena rebra i povređen jedan bubreg" i dodao izvod iz policijskog izveštaja u kome se kaže da su povrede „posljedica pada prilikom pokušaja bijega i skoka sa drugog sprata (tavana) kuće Svetine Kasolinija “. ${ }^{18}$ Tu se uloga Vladana Desnice završila, a presuda optuženima postala pravosnažna. Petoro navedenih dobilo je relativno kratke kazne zatvora (Majnarić i Anka Berus osuđeni su na po dve godine robije, Tonka Marić na godinu i po, a Vlak i Jelaska na godinu), uz dvogodišnji „gubitak časnih prava“. Uz to, Anka Berus je kažnjena „trajnim gubitkom državne službe“, sa obrazloženjem da „osuđeni pred ovim sudom ne mogu se baviti dalje vaspitanjem omladine". ${ }^{19}$

Cela ova priča daje jedan novi uvid u tek ovlaš pomenut i na ličnim sećanjima zasnovan sud o odnosu Vladana Desnice i Anke Berus posle Drugog svetskog rata, kada je Desnica već bio šef Pravne službe Ministarstva finansija Narodne Republike Hrvatske. Iako iz tog doba (od 1945. do 1950. godine) nema dokumenata koji bi potvrđivali bilo kakve sporove ili neprijatnosti koje je Desnica eventualno doživljavao u službi; iako je i sam Desnica,

\footnotetext{
Isto.

13 AJ 135-10/1936.

14 Isto.

15 Da je mučen u zagrebačkoj policiji, pak, tvrdio je na suđenju Vicko Jelaska. Videti: Lj. Ristović - S. KRŽAVAC, Robija, 66 .

16 AJ 135-10/1936.

17 U žalbi Ivana Ribara se zaista tvrdi da „sudija Državnoga suda za zaštitu države i sudsko vijeće bijahu vrlo korektni, i ponašahu se u okvirima zakona“. AJ 135-10/1936.

18 AJ 63-47/1936-88.

19 AJ $135-14 / 1936$
} 
žaleći se 1959. godine, u molbi za umetničku mirovinu, na hajku koja se vodi protiv njega, tvrdio da u navedenih pet godina nije za njega bilo nikakvih problema „ni u Ministarstvu financija NRH (...) ni u književnim krugovi$\mathrm{ma}^{\text {" } 20}$ - ipak postoji usmeno svedočanstvo da je Desnica bio u lošim odnosima sa tadašnjom hrvatskom ministarkom finansija Ankom Berus. To je tvrdio njegov brat od strica, Stojan Desnica: „Znam da se nisu podnosili; ona je bila ministrica, on šef Pravne službe, i gledali su se malo ovako... “21 Ivana Cvijović Javorina s pravom je bila oprezna komentarišući ovo svedočanstvo. ${ }^{22} \mathrm{Ne}$ sporeći da je Stojan Desnica bio uveren da je priča o sukobu Vladana Desnice i Anke Berus tačna, ona je iskazala rezervu, s obzirom da tu priču nije mogla da potvrdi niti uporednim svedočanstvima drugih članova porodice, a niti pisanim dokumentima, koji nesumnjivo imaju prednost nad knji-

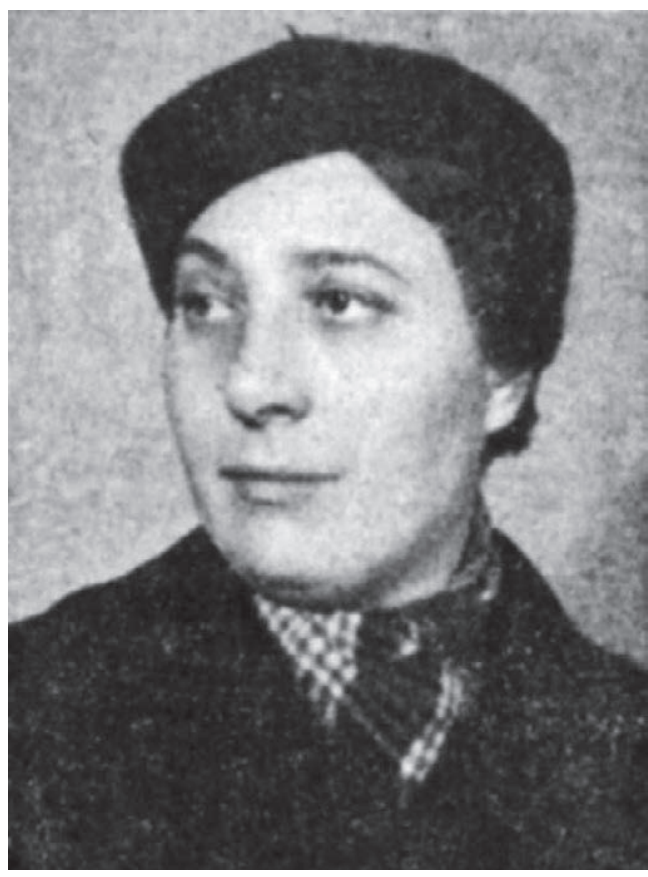

Sl. 1. Anka Berus nakon odsluženja zatvorske kazne 1938.

ževnim tekstovima i memoarskim svedočenjima. ${ }^{23}$ Ipak, dokumenta o istrazi i suđenju grupi splitskih komunista i simpatizera Komunističke partije svedoče o tome da su se, u jednom trenutku, 1936. godine, putevi Anke Berus i Vladana Desnice ukrstili. Anka Berus je posle rata, kao i svi oni koji su suđeni pred Sudom za zaštitu države, imala uvid u svoj predmet. No, to ne znači da je imala uvid i u Desničin izveštaj, koji nije bio deo predmeta, jer je bio poslat Ministarstvu pravde Kraljevine Jugoslavije, a ne Sudu za zaštitu države. Uostalom, izveštaj se ticao samo Ivana Majnarića, dok se Anka Berus nije žalila na postupanje policije prema njoj.

Međutim, polje mogućih pretpostavki se širi u svetlu detalja iz navedenih dokumenata Državnog suda za zaštitu države i sećanja Ivana Marića, pohranjenih u Arhivu Jugoslavije, u sklopu obimne memoarske građe za istoriju radničkog pokreta. U okviru veoma detaljne Marićeve izjave o razvoju radničkog organizovanja i komunističkog pokreta u Splitu

20 D. Roksandić, „Ratni dani Vladana Desnice“, 554.

21 Ivana Cvijović Javorina, „Obiteljska sjećanja na ratne dane Vladana Desnice“, Intelektualci i rat 1939. - 1947. Zbornik radova s međunarodnog skupa Desničini susreti 2011. (ur. Drago Roksandić i Ivana Cvijović Javorina), Zagreb 2012., 261.

22 Kada se ovakvim svedočanstvima nekritički pristupi, kada se ne upušta u proveru iznetih tvrdnji, onda se ona primaju zdravo za gotovo, i tada se odstupa od svih načela naučnog pristupa određenoj problematici. To se uvek, pa i u slučaju Vladana Desnice, čini sa zlom namerom, da bi se potkrepile sopstvene teze, makar one bile i neutemeljene. Tada se može razviti čitava priča o tobož moćnoj političkoj zaštiti koju je imao Vladan Desnica, i tada se može, u potpuno iskonstruisanom diskursu, implicitno nagovestiti da je ta zaštita išla po liniji nacionalnog identiteta. Ovakav primer etički sumnjivog pristupa videti u: Nikica BARIĆ, „Vladan Desnica - novi prilozi za biografiju“, Pilar, 8/2013., br. 15-16, 62 .

23 I. Cvijović Javorina, „Obiteljska sjećanja na ratne dane Vladana Desnice“, 262. 
između dva svetska rata (koja je pisana tokom 1963. godine na skoro stotinu strana), ovoj epizodi dato je vrlo malo prostora. Marićev iskaz doslovno glasi:

CK nas je upozorio s jednim pismom iz Beča da je provaljen Zembilj, da je sekretar Zembilja uhvaćen sa svim dokumentima. Provaljena je s njim i partijska tehnika, pa prema tome i naše javke. Anka Berus je imala javke (šifre) od dolaska Gorkića pa dalje. Radila je u tehnici, a nije bila partijski funkcioner. Preko tehnike, prva je bila provaljena Galić Anka (sad [1963] radi u NOO). Ona je bila veza Zembilja sa PK za Dalmaciju, a Majnarić njena veza sa Zembiljom. Anka je otkrila sve što je nosila Majnariću, a s Majnarićem je uhapšena i njegova žena Ines. Pod udarcima policije Majnariću su oslabili živci i sve je odao. ${ }^{24}$

Marićevo svedočenje važno je iz više aspekata. Najpre, ono govori o torturi kojoj su bili izloženi uhapšeni aktivisti. Na jednom mestu Marić je dodao: „Batinali su nas strahovito. “25 Posebno je važno naglašavanje torture kojoj je bio izložen Ivan Majnarić, jer je upravo taj slučaj bio povod Desničinom izveštaju. S druge strane, Marić je u svojoj izjavi direktno ukazao na tzv. loše držanje Anke Galić pred policijom, tj. da je od nje krenula serija hapšenja. Međutim, iz Marićeve izjave nepobitno sledi da je za provalu same Anke Galić kriva niko drugi nego Anka Berus, tj. njeno nepoštovanje pravila ilegalnog rada! Ona je „radila u tehnici“ (a Anka Galić je provaljena „preko tehnike“), ona je „preko Gorkića imala naše javke“, i to bez obzira na činjenicu da nije bila partijski funkcioner. Dakle, ako je Marić u svojoj izjavi pisanoj gotovo tri decenije posle ovih događaja optužio za loše držanje pod istragom Anku Galić i Ivana Majnarića, najveći deo odgovornosti prebacio je upravo na Anku Berus, zbog čije je neopreznosti i provaljena Anka Galić! ${ }^{26}$ Prema tome, mnogo toga u vezi sa Ankom Berus i njenom ulogom u hapšenju splitskih komunista i aktivista ostaje nedorečeno ili dvosmisleno. ${ }^{27}$ Gledajući danas, naravno, više nije bitno držanje uhapšenih ilegalaca pred policijom, s obzirom da je jasno da su svi bili izloženi ozbiljnoj torturi. Ipak, pošto su Ivan Marić i Vicko Jelaska isključeni iz Komunističke partije (posle rata imali su da prođu torturu i u kaznionicama svojih dojučerašnjih drugova), ostaje činjenica da je jedino Anka Berus ostvarila partijsku i političku karijeru, i posle oslobođenja zemlje bila je na relativno visokim funkcionerskim položajima. Da li je Vladan Desnica uopšte bio, i 1936. godine, ali i posle rata, upućen u celokupan slučaj provale u Pokrajinskom komitetu KP za Dalmaciju, da li je uopšte bilo pravog sukoba između njega i Anke Berus i da li je bar deo uzroka tog potencijalnog sukoba ležao u slučaju o kome govorimo - to sve ostaje još uvek u domenu pretpostavki. Međutim, dok se eventualno ne nađu još neka pisana svedočanstva, ostaje samo da se pribeleži važna i nepobitna činjenica da je Vladan Desnica, po

\footnotetext{
24 AJ Memoarska građa (516)-2061. Podvukao B. Đ. Sekretar Zembilja tada je bio Đorđe Mitrović.

25 AJ 516-2061.

26 Ivan Marić naglašava u svojoj izjavi da su svi uhapšeni dobili srazmerno male kazne, a neki od njih (kao i Marić) i oslobođeni isključivo zahvaljujući nepokolebljivom držanju Vicka Jelaske: „On nije priznao ništa u pitanju organizacije Partije, pa uhapšeni članovi komiteta nisu osuđeni na toj liniji.“ AJ 516-2061.

27 U svojoj vrlo kratkoj izjavi od 12. 6. 1961. godine, u kojoj nabraja članice Komunističke partije koje su sa njom bile u zatvoru u Požarevcu, Anka Berus samo u jednoj rečenici pominje kako se našla u zatvoru, tj. da je uhapšena posle provale „u splitskoj organizaciji“. AJ 516-2798.
} 
službenoj dužnosti, bio u jednom trenutku deo procesa koji se vodio protiv grupe splitskih komunista među kojima je bila i njemu docnije nadređena Anka Berus.

\section{IV}

Čak i kad bi se sporadično povela reč o književnim likovima u romanu Proljeća Ivana Galeba, što do sada u književnokritičkom i teorijskom pristupu Desničinom delu nije bilo često, lik Radivoja, đaka-komuniste, uglavnom je posmatran kao simbol svesne žrtve, ali i oličenje ideološke isključivosti i monomanije. Sva istraživanja svodila su odnos Ivana Galeba i Radivoja na dve ravni: empatično saosećanje sa žrtvom i kontrast liberalnih i dogmatskih ideja. Tako je i ova epizoda uglavnom služila da se potcrtaju filozofski i, eventualno, ideološki problemi koji muče glavnog junaka. Čak i ovde, gde se fakcija izrazito nametnula fikciji, izbegavalo se da se ukazuje na realni potencijal Desničine naracije, nego se uglavnom išlo ka ideološkom transponovanju cele ove epizode na samog Ivana Galeba, ${ }^{28}$ pri čemu je izvorni kontekst, a samim tim i književni lik Radivoja, uglavnom zanemarivan. Međutim, jedan od postulata teorije naracije jeste da je gotovo nemoguće ostvarivanje fikcionalnosti bez tzv. vantekstualnih elemenata, čiji je izvor najčešće u realnom prostoru i vremenu. $\mathrm{Na}$ ravno da se pri tome uvek mora računati na to da „svaki pokušaj da se predstavi stvarnost dovodi nužno do selektivne perspektive“. ${ }^{29}$ To je, uostalom, i jedna od privilegija umetničkog pripovedanja (jedan od osnovnih aristotelovskih postulata za razlikovanje umetnosti $\mathrm{i}$ istorije), koja čini da naracija nosi tzv. kulturni potencijal. ${ }^{30} \mathrm{Ali}$, jasno je da je Desnica u svoj roman ovu epizodu uneo i stoga što je 1936. godina, materijalizovana kalendarom na zidu bolničke sobe, godina u kojoj je bilo moguće - a za pripovedača moguće je uvek i nužno ${ }^{31}$ - da se dogodi slučaj kakav je predstavljen u romanu. U dosadašnjem pristupu romanu Proljeća Ivana Galeba, stoga, nije primećen realistični potencijal ove epizode, tj. da je ovo trenutak kada Ivan Galeb u najvećoj meri, metalepsično, izlazi iz zadate uloge rezonera i pripovedača, i otvara se prema drugom, makar i u nemuštoj raspravi sa njim. Pokazuje se tačnom Bahtinova opaska da „spomen na drugoga i njegov život u osnovi se razlikuje od posmatranja i sećanja na svoj sopstveni život" ${ }^{32}$ I bez obzira koliko Ivan Galeb želeo da

28 Tako je ova epizoda poslužila implicitnoj osudi „malograđanštine“ glavnog junaka, koja se sasvim uklapa u ondašnju atmosferu potcenjivanja Desnice kao pisca i prikrivene ideološke stigme. Videti: Duško CAR, „Igre proljeća i smrti“, Literatura, 2/1958., br. 9, 842. Ali, i kada se želi istaći ideološki potencijal Radivojevog i Galebovog agona (istina samo potencijalnog, s obzirom na Radivojevo ćutanje), opet se odlazi u drugu krajnost i insistira isključivo na kritici „monomanije“, a Radivoj tumači samo kao metafora dogmatizma. Videti: Davor Dukić - Goranka Šutalo, „Todesenthebung aus dem Sterbezimmer: koncepti ideologije i vlasti u recepciji Desničinih Proljeća Ivana Galeba“, Desničini susreti 2010. Zbornik radova (ur. Drago Roksandić i Ivana Cvijović Javorina), Zagreb 2011., 74.

29 3/1978., 61.

30 Alasdair MacIntyre, After Virtue, Notre Dame 1981., 211.

31 Louis Montrose, „New Historicisms“, Redrawing the Boundaries (ur. Stephen Greenblatt i Giles Gunn), New York 1992., 400.

32 Mihail Battin, Autor i junak u estetskoj aktivnosti, Novi Sad 1991., 116. 
„okrene leđa“ Radivoju, ${ }^{33}$ opet je ogorčen što ne može da dopre do njega: „Pa dobro, brate dragi, dokle ćemo tako? “34

Pravi izvor ove epizode, međutim, sada se može bez dileme detektovati. To su upravo pomenuti lekarski i policijski izveštaji o povredama Ivana Majnarića prilikom isleđivanja u splitskoj policiji, i to upravo iz 1936. godine! Tako se opet pokazuje da arhivski izvori mogu biti, ukoliko se uzmu sa kritičkim oprezom i pravilno protumače, pouzdan putokaz ka razrešenju izvesnih poetičkih dilema. Jer, kada kažemo da je cela afera sa splitskim komunistima suđenim 1936. godine pred Državnim sudom za zaštitu države, u koju je po dužnosti bio umešan i Vladan Desnica, poslužila kao izvor epizodi sa Radivojem u romanu, onda ne mislimo time samo na daleku, i uglavnom neuhvatljivu, najčešće implicitnu, motivsku vezu. Ne. U ovom slučaju radi se o arhivskom dokumentu kao prototekstu! Reč je o tome da je Vladan Desnica, zapravo, delove lekarskog i policijskog izveštaja u koje je imao uvid, i na osnovu kojih je sačinjavao i svoj izveštaj Ministarstvu pravde Kraljevine Jugoslavije, uvrstio u sam tekst romana. Već sama Galebova pretpostavka o razlozima Radivojevog zatočenja i isleđenja vrlo nalikuje na ono što je traženo u istrazi protiv Ivana Majnarića i njegovih drugova: „Nemam pojma što je to što su iz njega htjeli da izvuku. Po svoj prilici nešto što objektivno i nije od neke osobite važnosti: od koga je dobio da rastura letke ili nešto takvo. “35 Ali, kada bolničarka obavesti Ivana Galeba o Radivojevim povredama, i kada pročitamo: „Izgleda da mu je povrijeđen jedan bubreg“, ${ }^{36}$ onda smo se iz domena fikcije već sasvim približili domenu fakticiteta, pošto se u lekarskom izveštaju o povredama Ivana Majnarića čita da mu je „povrijeđen jedan bubreg“. A kad lekar objašnjava Ivanu Galebu da će kao uzrok Radivojeve smrti biti navedena „povreda traumatske prirode nepoznatog izvora " ${ }^{37}$ onda je to doslovna formulacija iz lekarskog izveštaja o Majnarićevim povredama! A kada te povrede splitska policija bude pokušala da prikaže kao posledicu „skoka sa drugog sprata“, onda to neminovno vodi do smrti kao posledice pada „s prozora petog kata“38 (pri čemu je, naravno, u sasvim logičnom kontekstu, sprat viši, jer je posledica tobožnjeg pada drastičnija).

No, ovde treba nešto jasno reći. Nema sumnje da su lekarski i policijski izveštaji iz 1936. godine poslužili kao neposredan izvor Desničinoj fikciji. Ali, radi se isključivo o izvoru naracije. Desnica, naime, nije uzeo realnog komunistu, Ivana Majnarića, za prototip svoga Radivoja. Radivoje ima realni potencijal, ali je on primarno fiktivni književni lik koji otelovljuje određene aposteme koje proizilaze isključivo iz sveta naracije. Realnost se ovde ukazuje samo kao moguć izvor naraciji. Jer, „identitet fikcionalnih osoba zaštićen je granicom između stvarnog i mogućeg (pripovedačkog) sveta“. ${ }^{39}$ Realno vreme i vreme naracije se razilaze u simboličkom potencijalu koji u sebi nosi i sam Radivoj i ova epizoda. Za Desnicu

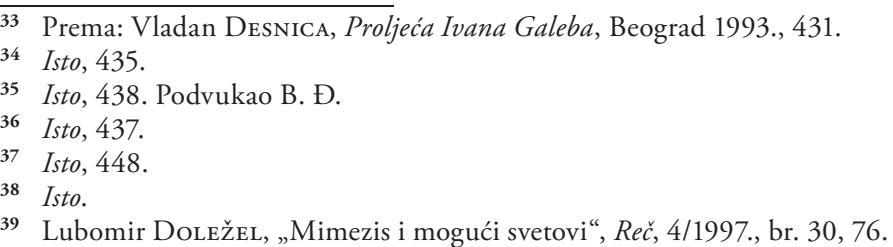


- Radivoj. Gotovo je. Donijeli su ga na obdukciju. Uprav ga sad dolje seciraju.

Tako dakle. Gotovo je. Nema više Radivoja. Sad mi se čini daleko, i čisto nestvarno, da je prije samilh nekoliko dana bio u ovoj istoj sobi, tu, pored mene, da sam mu se doticao čela ovim istim rukama ... Znači, izdržao je i ovog puta. Izdržao je, ali ga više 'nema. Nema više Radivoja.

Kasnije je došao i mladi doktor i najavio mi:

- Sutra se ide na operaciju. Odlučeno je.

Dakle ipak!

- ... Ali budite mirni, ovaj put je samo jedan manji zahvat.

Pomislio sam: to možda znači dva ili dva i po sata kasapljenja.

- A hoću li izdržati, doktore?

- Ne brinite! - površno se nasmiješio. - Vi ste još dosta jak! U vašem su kraju ljudi čvrsti, kao odvaljeni od stijene!

Sjeo je malo pored mene. Na licu mu je bila sjena zlovolje u vidu neke rasijanosti. Stari seljak povukao je svoju stolicu nekoliko centimetara natrag.

- Doktore, jeste li bili dolje? Kako izgleda?

Odmahnuo je rukom, gledajući ustranu.

- Strahota! Polomljena rebra, fraktura lubanje, odvaljen jedan bubreg.

- A što sad? - upitao sam besmisleno.

- Sad? Sad se dolje vodi diskusija izmedu liječnika i policajaca oko formulacije »uzroka smrti«. Natežu se. Liječnici se bore da koliko toliko spasu dostojanstvo. Prepirka se kreće u rasponu između "povreda traumatske prirode nepoznatog izvora" na jednoj strani, i »vitium cordis" ili čak "ritium cordis congenitale" na drugoj strani. Vjerovatno će se nagoditi negdje po sredini. na formuli »kljenut srca», tout court. U ovakvim slučajevima sve spasava ta formula. Naime, neposredni je uzrok smrti uvijek to što je srce prestalo kucati. Cak i onda kad se bacite s prozora petog kata, zajamčeno ne ćete umrijeti sve dotle dok vam srce ne prestane da radi. A zašto je srce prestalo raditi, to je drugo pitanje. No to pitanje izlazi van djelokruga liječničkog komisijskog nalaza. Dakle, »kljenut srca«, pa mir. Kao što vidite, spasonosan eufemizam koji ustvari znači otprilike kao kad biste rekli: umro je od smrti. I vuk sit $\mathrm{j}$ koza cijela.

- Da. Vuk sit i presit a koza zdrava i čitava. Samo Radivoja više nema.

- ... Dakle, pripremite se za sutra! - rekao je ustajući i potapšao me s ovlašnim ohrabrenjem po ramenu. - Nastojte da ne mislite mnogo na operaciju. Uzmite radijc knjigu pa čitajte nešto lijepo.

Otišao je. Slijepi seljak primaknuo je opet svoju stolicu pola pedlja bliže, te opet zuri u mene, spokojno, bez riječi. Tek, odjednom izbaci, neodredeno:

- He, što ćete. Svi ćemo tako!

$\mathrm{Pa}$ dalje sjedi, zuri u me, $i$ šuti. 
zaista važi ona istina da u jednom romanu ili pripoveci „čak i više od priče koja se priča, važniji je način na koji je ta priča ispričana“. ${ }^{40}$ Uostalom, za razliku od realnog prototipa, Ivana Majnarića, Radivoj izdržava - i umire. Time se pokazuje da je realni izvor - u ovom slučaju arhivski tekst, kao proizvod realnog vremena, uvek samo ekspozicija predmeta, dok je književni tekst, kao proizvod vremena naracije, uvek stvaranje predmeta. Ova distinkcija omogućava, zapravo, autonomnost književnog dela i u Desničinom slučaju je potpuno poštovana. ${ }^{41}$ Najzad, u tome leži i distinkcija Vladana Desnice-činovnika i Vladana Desnice-književnika. U izveštaju iz 1936. godine Desnica se ospoljio kao savestan i oprezan državni činovnik, koji prevashodno razmišlja o tome da li je došlo do zakonskog prekršaja, a ne do etičkog ogrešenja. U epizodi iz Proljeća Ivana Galeba svome naratoru, samom Ivanu Galebu, dao je da postupi i promišlja u etičkim okvirima, onako kako bi sigurno i sam pisac činio da je 1936. godine bio samo umetnik. Mišljenja smo da i u ovakvim dvojbama i unutarnjim borbama treba tražiti još jedan od razloga Desničinog konačnog napuštanja činovničke službe i okretanja putu koji je odavno izabrao, i koji je, zapravo, put individualne umetničke slobode, ona mogućnost da se krene „svim stazama odjednom“.42

\section{$\cos$}

\section{The Speech of a Literary Character and the Speech of a Document: An Episode in Proljé́a IVANA GaLEBA}

As a bureaucrat in the Split prosecution office, in 1936 Vladan Desnica was officially involved in a case regarding the uncovering of a communist group in Split that had been disseminating leaflets and brochures, as well as the party journal Proleter. The ensuing investigation pursued by the Split and Zagreb police led to the trial of five persons before the Court of state protection. Dr Ivan Ribar, attorney to the defendant Ivan Majnarić submitted an appeal to the Ministry of Justice of the Kingdom of Yugoslavia, in which he claimed that his client had been tortured on the premises of the Split police and that his confession had been extorted. The Ministry of Justice handed the case over to the Split prosecution office for further investigation. The report was submitted by senior attorney Vladan Desnica. Anka Berus, future finance minister of the People's Republic of Croatia was one of those convicted. Vladan Desnica was head of the legal department in this ministry at that time. Some testify about a rift between the two. Desnica's report from 1936 points to a moment when their paths crossed. This report, taken together with the documents of the Kingdom of Yugoslavia's Court of state protection and memories of those who took part in this event, such as Ivan Marić, shed further light on events regarding the history of the worker's and communist movement in Split and Dalmatia. In his report, however, Desnica - who limited himself to the question of police brutality against Ivan Majnarić - added parts from the medical and police report. By comparing these documents with an episode from Desnica's novel Proljeća Ivana Galeba, we arrive to the conclusion that parts of this report Desnica incorporated into the fabric of his novel. In one

\footnotetext{
40 Nelson Goodman, OfMind and Other Matters, Cambridge 1984., 137.

41 O ovome videti: John Langshaw Austin, How to Do Things with Words, Oxford 1962., 1-2. Takođe i: Wolfgang Iser, Die Appellstruktur der Texte: Unbestimmtheit als Wirkungsbedingung literarischer Prosa, Konstanz 1971., 9-10.

42 V. Desnica, Proljeća Ivana Galeba, 384.
} 
moment, the worlds of fact and fiction in which Desnica operated collided. An episode from his bureaucratic career, in a genuine time and space, had been transposed, even with a documentary basis, into the imaginary fictional time and space of novelistic prose.

Keywords: Vladan Desnica, Split, communist movement, document, literary character, prototext

\section{$\cos$}

\section{Izvori}

Arhiv Jugoslavije, Državni sud za zaštitu države (135).

Arhiv Jugoslavije, Ministarstvo pravde Kraljevine Jugoslavije (63).

Vladan Desnica, Proljeća Ivana Galeba, Beograd 1993.

\section{Literatura}

John Langshaw Austin, How to Do Things with Words, Oxford 1962.

Mihail Bahtin, Autor i junak u estetskoj aktivnosti, Novi Sad 1991.

Nikica BARIĆ, „Vladan Desnica - novi prilozi za biografiju“, Pilar, 8/2013., br. 15-16, 9-67.

Duško CAR, „Igre proljeća i smrti“, Literatura, 2/1958., br. 9, 840-843.

Ivana Cvijović Javorina, „Obiteljska sjećanja na ratne dane Vladana Desnice“, Intelektualci i rat 1939. - 1947. Zbornik radova s međunarodnog skupa Desničini susreti 2011. (ur. Drago Roksandić i Ivana Cvijović Javorina), Zagreb 2012., 255-266.

Vladan Desnica, Hotimično iskustvo: diskurzivna proza Vladana Desnice. Knjiga druga (prir. Dušan Marinković), Zagreb 2006.

Lubomir DoležEl, „Mimezis i mogući svetovi“, Reč, 4/1997., br. 30, 74-83.

Davor Dukić - Goranka Šutalo, „Todesenthebung aus dem Sterbezimmer: koncepti ideologije i vlasti u recepciji Desničinih Proljeća Ivana Galeba", Desničini susreti 2010. Zbornik radova (ur. Drago Roksandić i Ivana Cvijović Javorina), Zagreb 2011., 62-77.

Nelson Goodman, Of Mind and Other Matters, Cambridge 1984.

Wolfgang Iser, Die Appellstruktur der Texte. Unbestimmtheit als Wirkungsbedingung literarischer Prosa, Konstanz 1971.

Alasdair MacIntyre, After Virtue, Notre Dame 1981.

Louis Montrose, „New Historicisms“, Redrawing the Boundaries (ur. Stephen Greenblatt i Giles Gunn), New York 1992., 387-422.

Ludwig Pfeifer, „The Novel and Society: Reflections on the Interactions of Literary and Cultural Paradigmas“, PTL, 3/1978., 57-78.

Ljubiša Ristović - Savo KrŽAvac, Robija. Kovačnica komunista, sv. 2, Zagreb 1968.

Drago Roksandić, „Ratni dani Vladana Desnice“, Intelektualci i rat 1939. - 1947. Zbornik radova $s$ mectunarodnog skupa Desničini sureti 2012. (ur. Drago Roksandić i Ivana Cvijović Javorina), sv. 2, Zagreb 2013., 528-555. 